\title{
THE PROBLEM WITH FORGIVING (BUT NOT ENTIRELY FORGETTING) THE CRIMES OF OUR NATION'S YOUTH: EXPLORING THE THIRD CIRCUIT'S UNCONSTITUTIONAL USE OF NONJURY JUVENILE ADJUDICATIONS IN ARMED CAREER CRIMINAL SENTENCING
}

\author{
Stephen F. Donahoe*
}

Due process is that which comports with the deepest notions of what is fair and right and just.

Former Supreme Court Justice Felix Frankfurter ${ }^{1}$

Only by zealously guarding the rights of the most humble, the most unorthodox and the most despised among us can freedom flourish and endure in our land.

\section{Former Supreme Court Justice Frank Murphy²}

\section{INTRODUCTION}

For better or for worse, our Constitution ensures that the basic rights of fair procedure are guaranteed to all American citizens, including those accused of crime, no matter how much society may disapprove of their actions. ${ }^{3}$ The United States Supreme Court has expressly provided that "[d]ue process of law is the primary and indispensable foundation of individual freedom" and effectively serves as the "basic and essential term in the social compact which defines the rights of the individual and delimits the powers which the state may exercise." ${ }^{4}$ Recognizing that the failure to observe fundamental procedural due process guarantees has historically resulted in substantial unfairness to criminal defendants, ${ }^{5}$ the Court has worked to

* J.D., May 2005. The author would like to thank retired Professor Robert Berkley Harper for his guidance and scholarly feedback. The author would also like to especially thank Kristen for her constant patience and support.

1. Solesbee v. Balkcom, 339 U.S. 9, 16 (1950) (Frankfurter, J., dissenting).

2. Bridges v. Wixon, 326 U.S. 135, 165 (1945) (Murphy, J., concurring).

3. See, e.g., U.S. Const. amends. IV, V, VI, VIII, XIV.

4. $\quad$ In re Gault, 387 U.S. 1, 20 (1967).

5. Id. at 19-20 (noting that in criminal trials, "[f]ailure to observe the fundamental requirements of due process has resulted in instances, which might have been avoided, of unfairness to individuals and 
establish heightened procedural safeguards in criminal proceedings over the latter half of the past century. ${ }^{6}$ In this sense, the Court has openly embraced the belief that "the progression of history, and especially the deepening realization of the substance and procedures that justice and the demands of human dignity require" has called for courts to "invest the command of "due process of law' with increasingly greater substance." Consequently, the Supreme Court has set a clear example that lower courts must move forward "with advancing the conception of human rights in according procedural as well as substantive rights to individuals accused of conflict with the criminal laws."

Nevertheless, in its June 2003 ruling in United States v. Jones, ${ }^{9}$ the Third Circuit Court of Appeals radically departed from this standard and compromised criminal defendants' procedural due process rights when it upheld a federal district court's decision to extend an adult repeat felon's sentence, in part because of a prior nonjury juvenile adjudication. In doing so, the Third Circuit effectively failed to recognize that certain fundamental differences between the juvenile and adult criminal justice systems make it both unjust and unconstitutional to permit a judge to use a prior nonjury juvenile adjudication against a defendant in an adult criminal sentencing hearing. Because the adult and juvenile justice systems seek to serve separate and sometimes conflicting objectives, juvenile adjudications, like the one at issue in Jones, often lack many of the basic procedural safeguards, such as the right to a trial by jury, that are afforded to defendants in adult criminal proceedings. These opposing philosophies and relaxed procedures reinforce the idea that the nation's juvenile courts seek to arrive at a different sort of justice, and consequently make it patently and procedurally unfair for sentencing judges to use the sort of nonjury adjudications associated with this system interchangeably with prior adult convictions.

It follows, then, that the purpose of this Note is essentially twofold. First, it simply seeks to expose the central flaws in the rationale articulated by the Third Circuit in Jones. Second, it attempts to offer a more constitutionally sound alternative for future courts faced with the task of determining whether a nonjury juvenile adjudication can be used to enhance a criminal defendant's subsequent adult sentence. To accomplish these tasks, this commentary

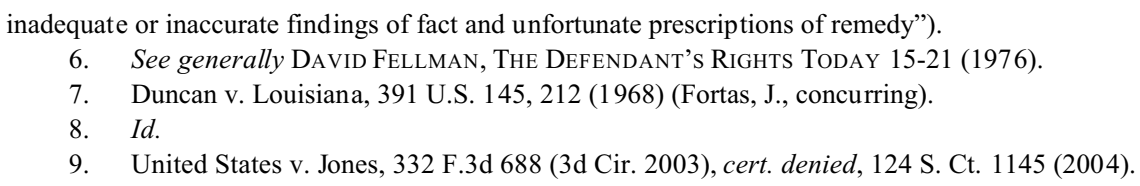


begins by exploring the Third Circuit's ruling in Jones and discussing the ways that various other federal appellate courts have responded to nearly identical factual circumstances. Next, it briefly outlines the historical origins and development of the American juvenile system, and relays how the "rehabilitative ideal" on which that system was founded continues, at least in part, to govern adjudications in the nation's juvenile courts. Finally, this Note concludes by emphasizing the ways that this focus on rehabilitation has substantially limited the constitutional procedural safeguards afforded to young offenders in comparison with those enjoyed by adult criminal defendants. Ultimately, it is my hope that the reader will arrive at the same conclusion that this Note emphatically reaches, and embrace the idea that using prior nonjury juvenile adjudications to extend subsequent adult sentences clearly deprives a criminal defendant of liberty without due process of law.

\section{BACKGROUND}

In April 2000, a federal judge for the Western District of Pennsylvania sentenced Lester Jones to fifteen years in prison after he pleaded guilty to being a felon in possession of a firearm. ${ }^{10}$ In most cases, a defendant convicted of such a crime is subject to a maximum sentence of ten years imprisonment. ${ }^{11}$ However, the Armed Career Criminal Act ("ACCA") mandates a minimum sentence of fifteen years in prison for any individual convicted of being a felon in possession of a firearm who has had three prior convictions for a violent felony or serious drug offense. ${ }^{12}$ At the time of his guilty plea, the district court found that Jones had two state felony drug convictions as an adult and one prior juvenile adjudication for the violent crime of aggravated assault. ${ }^{13}$ The court then determined that these prior offenses properly constituted the requisite three past convictions needed for a sentencing judge to invoke the ACCA and ordered Jones to serve fifteen years in prison. ${ }^{14}$

10. Jones, 332 F.3d at 690 . According to the Third Circuit Court of Appeals, three witnesses claimed that on April 10, 2000, Jones entered an apartment in Pittsburgh, Pennsylvania, where he "displayed two guns, one of which he discharged twice" and then "threatened the occupants and fled the apartment with $\$ 10,000$ in cash and some clothing." Id. Jones later admitted to possessing the weapons but denied ever robbing anyone. $I d$. at $690 \& \mathrm{n} .1$.

11. See 18 U.S.C. $\S 924(a)(2)(2000)$.

12. Id. § 924(e).

13. Jones, 332 F.3d at 690.

14. See id. at $690-98$. 
On appeal, Jones requested that the Third Circuit Court of Appeals vacate his sentence and remand for resentencing with instructions that he be sentenced without the application of the ACCA. ${ }^{15}$ Although Jones did not dispute the district court's ruling regarding his two prior adult drug convictions, he maintained that because he was not afforded the right to a jury trial during his juvenile adjudication, the results of that juvenile proceeding could not constitute a third prior conviction that would trigger the ACCA's sentence-enhancing provision. ${ }^{16}$

Relying on the Supreme Court's decision in Apprendi v. New Jersey, ${ }^{17}$ the Third Circuit concluded that Jones was afforded all of the procedural safeguards that he was constitutionally due and that the district court had properly enhanced his sentence pursuant to the ACCA. ${ }^{18}$ In Apprendi, the United States Supreme Court expressly provided that any fact that "increases the penalty for a crime beyond the prescribed statutory maximum must be submitted to a jury, and proved beyond a reasonable doubt."19 After making this broad holding, however, the Apprendi Court then articulated an exception to its rule, stating that future courts may indeed use a fact of a prior conviction to increase the penalty for a crime beyond the appropriate statutory maximum, even if it is not submitted to a jury. ${ }^{20}$ In deciding that Jones's prior nonjury juvenile adjudication fell within the Supreme Court's Apprendi exception, the Third Circuit paid special attention to the fact that although juveniles generally do not have the right to a trial by jury, ${ }^{21}$ they enjoy other procedural guarantees that satisfy constitutional standards, which help ensure that they receive due process of law. ${ }^{22}$ As a result, the Jones court concluded that "[a] prior nonjury juvenile adjudication that was afforded all constitutionallyrequired procedural safeguards can properly be characterized as a prior conviction for Apprendi purposes." 23

\footnotetext{
15. Id. at 690 .

16. Id.

17. Apprendi v. New Jersey, 530 U.S. 466 (2000).

18. Jones, 332 F.3d at 696.

19. Apprendi, 530 U.S. at 490

20. $I d$.

21. See McKeiverv. Pennsylvania, 403 U.S. 528 (1971) (holding that due process does not require providing juveniles with the right to a jury trial).

22. Jones, 332 F.3d at 696 . According to the Jones court, "juvenile defendants receive process that has been held to satisfy constitutional standards, including the right to notice, right to counsel, right to confront and cross-examine witnesses, and the privilege against self-incrimination." Id.

23. $I d$.
} 
Because the Apprendi Court failed to address the unique issues that distinguish juvenile adjudications from adult criminal proceedings, ${ }^{24}$ the federal appellate courts remain split over whether prior juvenile adjudications that do not afford the right to a jury trial should fall within its "prior conviction" exception. ${ }^{25}$ For example, in United States v. Tighe, the first federal appellate case involving this precise issue, the Ninth Circuit expressly limited Apprendi's scope to cover only prior convictions that were themselves the result of a proceeding that included the right to a trial by jury. ${ }^{26}$ In Tighe, the defendant pled guilty to a three-count indictment charging him with bank robbery, being a felon in the possession of a firearm, and interstate transportation of a stolen vehicle. ${ }^{27}$ At his sentencing hearing, the federal district court relied on a prior nonjury juvenile adjudication for reckless endangerment, first-degree robbery, and unauthorized use of a motor vehicle to constitute one of the requisite "three strikes" needed to implement the enhanced sentencing provisions of the ACCA. ${ }^{28}$ The Ninth Circuit reversed the district court's application of the ACCA and remanded the case for resentencing. ${ }^{29}$ Citing language from the Court's opinion in Apprendi, the court made clear that:

There is a vast difference between accepting the validity of a prior judgment of conviction entered in a proceeding in which the defendant had the right to a jury trial and the right to require the prosecutor to prove guilt beyond a reasonable doubt, and allowing the judge to find the required fact under a lesser standard of proof. ${ }^{30}$

Accordingly, the Ninth Circuit concluded that the Supreme Court's decision in Apprendi was premised on the idea that sentencing-enhancing prior convictions should be limited to those that were the product of proceedings affording individuals the "crucial procedural protections" outlined in the Constitution. $^{31}$

24. See generally Apprendi, 530 U.S. at 466.

25. Compare United States v. Tighe, 266 F.3d 1187, 1194 (9th Cir. 2001) (holding that the "prior conviction" exception to Apprendi's general rule must be limited to prior convictions that were themselves obtained through proceedings that included the right to a jury trial), with United States v. Smalley, 294 F.3d 1030, 1033 (8th Cir. 2002) (concluding that nonjury juvenile adjudications "can rightly be characterized as 'prior convictions' for Apprendi purposes").

26. Tighe, 266 F.3d at 1194 .

27. Id. at 1190 .

28. Id.

29. Id. at 1197-98.

30. Id. at 1194 (quoting Apprendi v. New Jersey, 530 U.S. 466, 496 (2000)).

31. Id. 
Conversely, a year later in United States v. Smalley, the Eighth Circuit rejected the rationale articulated in Tighe and employed the same logic expressed by the Jones court when it determined that past nonjury juvenile adjudications should indeed constitute "prior convictions" under Apprendi. ${ }^{32}$ In Smalley, after the defendant pled guilty to being a felon in possession of a firearm, the district court, employing the provisions of the ACCA, extended his adult sentence from ten to fifteen years in prison based in part on prior nonjury juvenile adjudications. ${ }^{33}$ The Smalley court, like the Third Circuit in Jones, determined that "it is incorrect to assume that it is not only sufficient but necessary that the 'fundamental triumvirate of procedural protections,' as the Ninth Circuit put it [in Tighe], underly an adjudication before it can qualify for the Apprendi exemption." ${ }^{34}$ Consequently, the court concluded that "the question of whether juvenile adjudications should be exempt from Apprendi's general rule should not turn on the narrow parsing of words, but on an examination of whether juvenile adjudications, like adult convictions, are so reliable that due process of law is not offended by such an exemption." ${ }^{35}$ Noting that young offenders enjoy the right to counsel, the right to notice, the right to confront and cross-examine witnesses, and the privilege against self-incrimination, the Smalley court maintained that these procedural safeguards were adequate to ensure the degree of reliability sufficient to constitute a valid "prior conviction" under Apprendi. ${ }^{36}$

The obvious tension between the Ninth Circuit's holding in Tighe and the reasoning proffered in both Jones and Smalley demonstrates that the federal courts of appeals are divided over whether prior nonjury juvenile adjudications can be used to enhance subsequent adult sentences under the language of the ACCA. In this sense, it seems that unless the Supreme Court resolves the issue once and for all, the federal circuits will remain conflicted and continue to produce inconsistent and contrasting precedent for the nation's district courts. Hence, without the Court's further guidance, sentencing judges across the country will continue to apply different standards to determine whether a particular adult defendant should be classified as an "armed career criminal," thereby imposing unequal punishments on otherwise similarly situated offenders.

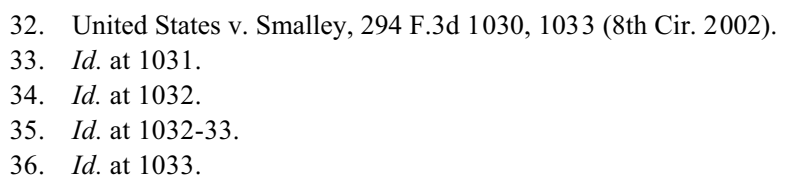




\section{Discussion}

The Fifth Amendment to the United States Constitution provides that, in federal criminal proceedings, no individual shall be deprived of life or liberty "without due process of law." ${ }^{37}$ This Amendment accurately reflects the idea that procedural due process, like almost every other aspect of American public law, is deliberately weighed in favor of criminal defendants. ${ }^{38}$ Arguably, the most important reason for providing criminal defendants with certain fundamental procedural safeguards is that every criminal case is a dispute between individual citizens and the government. ${ }^{39}$ Because modern government is such a powerful institution, and individual defendants have significantly less strength in comparison, it follows that a criminal proceeding is an inherently unequal contest. ${ }^{40}$ In this sense, "the disparity between [the government and a solitary criminal defendant] is of such magnitude that without safeguards injustice is almost inevitable in many situations, since inequality begets injustice." ${ }^{\prime 1}$ Accordingly, it has been widely accepted that "[s]teadfast adherence to strict procedural safeguards is our main assurance that there will be equal justice under law." ${ }^{42}$

In Jones, the Third Circuit seemingly lost sight of this guiding principle when it incorrectly held that juvenile adjudications subject to less rigid due process standards than those afforded to defendants in adult criminal proceedings should count towards the "three strikes" necessary for a judge to trigger the harsher sentencing requirements of the ACCA. ${ }^{43}$ In order to expose the inherent flaws in the Third Circuit's reasoning, it is necessary to explore both the foundation and historical development of the American juvenile justice system, as well as the ways that this system of justice continues to remain separate and distinct from its adult criminal counterpart. Such an analysis reveals that a better, and certainly more constitutional, approach for courts faced with similar dilemmas would be to follow the Ninth Circuit's lead in Tighe and hold that the "prior conviction" exception to Apprendi's general rule must be limited to prior convictions that were themselves obtained

37. U.S. CONST. amend. V.

38. Fellman, supra note 6 , at 3 .

39. Id. at 4 .

40. Id.

41. Id.

42. E.g., Joint Anti-Fascist Refugee Comm. v. McGrath, 341 U.S. 123, 179 (1951) (Douglas, J., concurring).

43. See supra Part II (discussing Jones, Tighe, and Apprendi). 
through proceedings that afforded individual defendants the same procedural safeguards they would be entitled to in the adult criminal justice system. ${ }^{44}$

\section{A. The Origins and Evolution of the American Juvenile Justice System}

In the early twentieth century, advances in industrialization and modernization led to the increasingly accepted view that "children were "corruptible innocents whose upbringing ... required greater structure than had previously been regarded as prerequisite to adulthood." ${ }^{45}$ During this period, many social scientists began to feel that because children were neither completely mentally nor physically developed, they should not be held fully accountable for their actions like adult criminal offenders. ${ }^{46}$ Further, these scholars argued that criminal behavior in children was largely the result of external factors, such as poor living conditions or parental neglect, and viewed juvenile criminality as a sort of "youthful illness" that could be cured by moving young offenders to more stable and healthy environments. ${ }^{47}$

As a result of these developing concerns and attitudes, state legislatures created a separate system of justice to protect juveniles and provide them with a type of treatment that would enable them to become productive members of society. ${ }^{48}$ The purpose of this new system of justice was to rehabilitate offenders rather than to serve the traditional purposes of punishment or deterrence generally associated with the adult criminal courts. ${ }^{49}$ Evoking the

44. $I d$.

45. See Christine Chamberlin, Not Kids Anymore: A Need for Punishment and Deterrence in the Juvenile Justice System, 42 B.C.L. Rev. 391, 394 (2001) (quoting Barry C. Feld, The Juvenile Court Meets the Principle of Offense: Punishment, Treatment and the Difference It Makes, 68 B.U. L. REv. 821, 822 n.5 (1998)).

46. Chamberlin, supra note 45 , at 394 .

47. Id. at 394-95.

48. Id. at 395 .

49. Id. at 394 ("Generally speaking, while the adult criminal justice system emphasizes the punishment of criminals, the juvenile system is based on the rehabilitation of juvenile offenders."). See also Brandi Miles Moore, Blended Sentencing for Juveniles: The Creation of a Third Criminal Justice System?, 22 J. Juv. L. 126, 127 (2002) (quoting In re E.Q., 839 S.W.2d 144, 146 (Tex. App. 1992), and Shannon F. McLatchey, Juvenile Crime and Punishment: An Analysis of the "Get Tough" Approach, 10 U. FLA. J.L. \& PuB. POL'y 401, 403 (1999)) (explaining that the juvenile justice system "was based on the principle that "the state must care for those who cannot take care of themselves"” and sought to " insulate minors from the harshness of criminal prosecutions, to promote rehabilitation over punishment, and to eliminate the taint of criminal conviction after incarceration by characterizing such actions as delinquent rather than criminal'"); Howard N. Snyder \& Melissa Sickmund, Office of Juvenile Justice And Delinquency Prevention, Juvenile Offenders and Victims: 1999 National Report 86 (1999) ("The juvenile justice system was founded on the concept of rehabilitation through individualized justice.”). 
doctrine of parens patriae, ${ }^{50}$ which essentially views the state as a sort of surrogate parent, the juvenile courts removed children from the adult correctional system and subjected them to civil proceedings that stressed "treatment, supervision, and control" as an alternative to punishment. ${ }^{51}$ This "“rehabilitative ideal' envisioned a specialized judge trained in social science and child development whose empathic qualities and insight would enable her to make individualized therapeutic dispositions in the 'best interests' of the child." ${ }^{52}$ Accordingly, the early juvenile courts approached a young offender's crimes primarily as a symptom of his or her "real needs" and oftentimes did not heavily weigh the nature of the actual offense when determining the appropriate degree or duration of state intervention. ${ }^{53}$ In this sense, "[t]he goal was to determine why the child was in court in the first instance and what could be done to change the character, attitude, and behavior of the youth to prevent a reappearance." 54

For the first half of the twentieth century, the juvenile courts' focus on offenders and not offenses, and on rehabilitation rather than punishment, significantly compromised the procedural due process rights of young offenders. ${ }^{55}$ In the juvenile courtroom, delinquency proceedings were much more informal than in the adult criminal system and "due process protections afforded criminal defendants were deemed unnecessary." early juvenile courts generally failed to grant young offenders many of the traditional procedural safeguards afforded to adult criminal offenders:

50. See Black's Law Dictionary 1137 (7th ed. 1999) (defining the doctrine of parens patriae as instances where the state acts "in its capacity as provider of protection to those unable to care for themselves").

51. Barry C. Feld, Abolish the Juvenile Court: Youthfulness, Criminal Responsibility, and Sentencing Policy, 88 J. CRIM. L. \& Criminology 68, 71 (1997).

52. $I d$.

53. Id. at 72 .

54. Barry C. Feld, Justice For Children: The Right to Counsel and the Juvenile Courts 16 (1993) [hereinafter Feld, Justice For ChiLdRen].

55. See, e.g., Snyder \& Sickmund, supra note 49, at 86. See also Barry C. Feld, Juvenile and Criminal Justice Systems' Responses to Youth Violence, 24 CRIME \& Just. 189, 192 (1998) ('By separating children from adults and providing a rehabilitative alternative to punishment, juvenile courts rejected both the criminal law's jurisprudence and its procedural safeguards ...."); Amanda K. Packel, Juvenile Justice and the Punishment of Recidivists Under California's Three Strikes Law, 90 CAL. L. REv. 1157, 1160 (2002) ("Moreover, to meet the specific rehabilitative needs of each child, the juvenile courts favored flexibility at the expense of formal processes.").

56. Snyder \& Sickmund, supra note 49, at 87. See also Feld, Justice For Children, supra note 54 , at 16 ("In separating children from adult offenders, the juvenile court also rejected the procedures of criminal prosecutions. It introduced a euphemistic vocabulary and a physically separate court building to avoid the stigma of adult prosecutions, and it modified courtroom procedures to eliminate any implications of a criminal proceeding.") (citation omitted). 
For example, proceedings were initiated by a petition in the welfare of the child, rather than by a criminal complaint or indictment. Because the important issues involved the child's background and welfare rather than the commission of a specific crime, courts dispensed with juries, lawyers, rules of evidence, and formal procedures. As the Pennsylvania Supreme Court noted, "Whether the child deserves to be saved by the state is no more a question for a jury than whether the father, if able to save it, ought to save it." ${ }^{57}$

Moreover, to avoid stigmatizing young offenders, juvenile hearings were confidential and closed to the public and youths were found to be "delinquent" rather than "guilty" of a given offense. ${ }^{58}$ Finally, juvenile court judges were traditionally actively hostile towards the presence of attorneys in delinquency proceedings. ${ }^{59}$ In this sense, because they viewed their aims to be benevolent and their interventions guided by science, juvenile courts operated on the underlying assumption that there was no real need for them to "narrowly circumscribe the power of the state." ${ }^{60}$

In the 1950s and 1960s, however, as increases in juvenile crime led the public at large to begin questioning the ability of the juvenile court system to adequately rehabilitate delinquent youth, the juvenile system started to embrace punitive objectives to supplement, but not replace, its original rehabilitative ideals. ${ }^{61}$ As a result of these changes, many individuals began to demand heightened procedural due process safeguards for youth delinquency proceedings. ${ }^{62}$ In turn, the United States Supreme Court, which had, for the most part, previously refrained from intervening in the realm of juvenile criminal justice, responded to the growing awareness of the limitations of the juvenile system with a series of judicial opinions that enhanced the degree of procedural due process afforded to young offenders and altered the character of the juvenile courts. ${ }^{63}$

57. Feld, Justice For Children, supra note 54, at 16 (quoting Commonwealth v. Fisher, 213 Pa. $48,54(1905))$.

58. $I d$.

59. Id. ("Although judges could not banish a lawyer from the courtroom altogether, they did not consider his presence either appropriate or necessary.") (quoting DAVID J. RothMAN, ConsCIENCE AND Convenience: The Asylum and its Alternatives in Progressive America 216 (1980)).

60. Id. at 15 .

61. SNYDER \& SiCKMUND, supra note 49 , at 87.

62. Id.

63. Id. at 87,90 (noting that "U.S. Supreme Court cases have had an impact on the character and procedures of the juvenile justice system”). See also BARRY KRISBERG \& JAMES F. Austin, ReINVEnTING JuvENILE Justice 49 (1993). 
In its 1967 In re Gault ${ }^{64}$ decision, the Supreme Court embarked on what many legal scholars regard as a "due process revolution" that effectively "transformed the juvenile court from a social welfare agency into a legal institution." ${ }^{65}$ After reflecting on the history of the juvenile system, the Gault Court concluded that a juvenile justice process free of constitutionally imposed procedural safeguards had not abated recidivism or lowered the crime rate associated with young offenders. ${ }^{66}$ Consequently, citing the "fundamental fairness" requirements outlined in the Fourteenth Amendment, the Court held that juveniles were constitutionally entitled to at least "advance notice of charges, a fair and impartial hearing, assistance of counsel, opportunity to confront and cross-examine witnesses, and the privilege against selfincrimination." ${ }^{97}$ Hence, while the Court's holding was narrowly confined to the actual adjudication of guilt or innocence in ajuvenile proceeding, the basis for its analysis of what constitutional rights should be afforded to young offenders was undoubtedly broad:

It asserted that its decision would in no way impair the value of the unique procedures for processing and treating juveniles and that the procedural safeguards associated with the adversarial process were essential in juvenile proceedings, both to determine the truth and to preserve individual freedom by limiting the power of the state. ${ }^{68}$

In the decade or so after its Gault decision, the Supreme Court also extended certain other procedural due process rights to juveniles. ${ }^{69}$ For example, in In re Winship, ${ }^{70}$ the Court determined that proof of a juvenile's delinquency must be established by "proof beyond a reasonable doubt" rather than the "preponderance of the evidence" evidentiary standard normally evoked in civil judicial proceedings. ${ }^{71}$ Similarly, in Breed v. Jones, ${ }^{72}$ the Court provided that after a conviction in juvenile court, the Fifth Amendment's double jeopardy clause prevents a state from engaging in the adult criminal prosecution of a youth for the same offense..$^{73}$ These decisions,

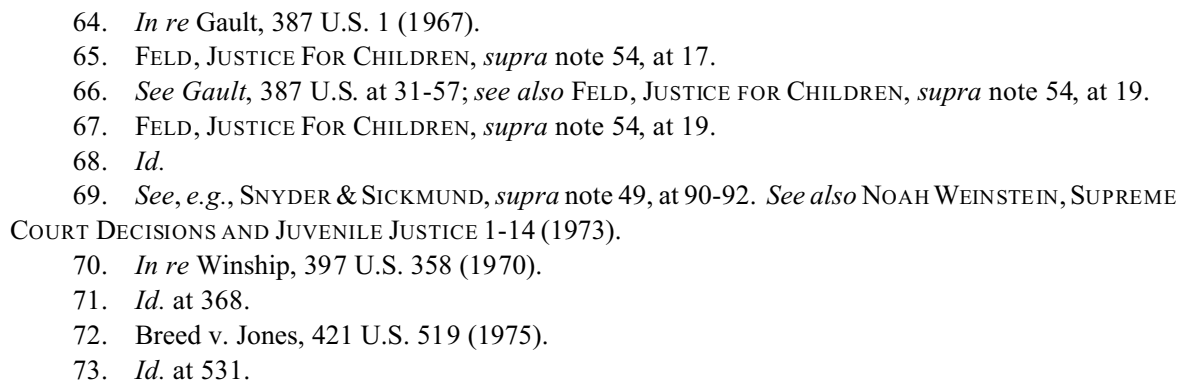


like the Court's earlier ruling in Gault, adequately reflect the Court's view that the "expansion of constitutional rights and limitation on the coercive powers of the state could be obtained through the adversary process, which in turn would assure the regularity of law enforcement and reduce the need for continued judicial scrutiny." 74

\section{B. Fundamental Differences Between the Modern Adult and Juvenile Criminal Justice Systems}

Despite the Supreme Court's efforts to narrow the gap between the adult and juvenile criminal justice systems in Gault and other subsequent decisions, certain important differences nevertheless remain between the two correctional systems that distinguish the juvenile courts from their adult criminal counterparts. First, the juvenile courts continue to value, at least to some extent, the concept of rehabilitation as both an important and an attainable goal. Secondly, and perhaps more importantly, even in the wake of Gault, the juvenile courts do not offer young offenders all of the procedural safeguards afforded to adult criminal defendants. Most notably, the juvenile court system generally does not provide a youth with the right to a trial by jury before declaring him or her as a delinquent. Because of these two important philosophical and procedural disparities, the juvenile and adult criminal justice systems remain distinct and fundamentally different systems of justice.

\section{The Juvenile Justice System Continues To View the Idea of Rehabilitation as a Central and Important Guiding Principle}

Although some scholars feel that the juvenile system is moving away from its rehabilitative origins and adopting the more punitive and deterrent aims of the adult criminal system, the "rehabilitative ideal" continues to serve as a significant and important element of adjudications in a majority of American jurisdictions. ${ }^{75}$ Hence, despite acknowledging punitive goals, juvenile jurisprudence has not abandoned the notion that:

The purpose of juvenile proceedings remains markedly different from that of adult proceedings. The state's purpose in juvenile proceedings is a rehabilitative one distinguishable from the criminal justice system for adults, which has a purely punitive

74. Feld, Justice For Children, supra note 54, at 21.

75. See, e.g., SNYDER \& SicKMUND, supra note 49 , at 87 (discussing different techniques used to achieve rehabilitation goal). 
purpose separate from its rehabilitative goals .... While part of the juvenile justice system does include punishment in certain cases, it does not change the primary purpose of juvenile proceedings from that of preserving and promoting the welfare of the child. ${ }^{76}$

In this sense, legal thinkers have noted that "even while there is evidence that the juvenile court is becoming more punitive, neither legislatures nor courts are yet willing to abandon the goal of rehabilitation." 77

On top of these scholarly observations, a majority of state juvenile court systems themselves have continued to expressly identify rehabilitation as a central philosophical aim. ${ }^{78}$ For example, a 1999 National Report issued by the federal Office of Juvenile Justice and Delinquency Prevention showed that, in 1997, over thirty state juvenile codes listed rehabilitation as a "philosophical goal" in their purpose clauses. ${ }^{79}$ Interestingly, included among these jurisdictions was Pennsylvania, ${ }^{80}$ where Lester Jones was originally adjudicated "delinquent" prior to pleading guilty to being a felon in possession of a firearm. ${ }^{81}$ According to the general purpose statement preceding the Pennsylvania Juvenile Act, state juvenile judges should interpret and construe the Act's provisions in a manner that gives effect to the following objective:

Consistent with the protection of the public interest, to provide for children committing delinquent acts programs of supervision, care and rehabilitation which provide balanced attention to the protection of the community, the imposition of accountability for offenses committed and the development of competencies to enable children to become responsible and productive members of the community. ${ }^{82}$

Similarly, a 2003 Pennsylvania Juvenile Delinquency Benchbook, issued to all state juvenile judges as a reference guide to assist them in their official capacity, lists "youth redemption" as one of the three central operating principles of the state juvenile courts in its "Pennsylvania Juvenile Justice

76. Packel, supra note 55, at 1164 (quoting In re Myresheia W., 72 Cal. Rptr. 2d 65, 68-69 (Cal. Ct. App. 1998)).

77. Julianne P. Sheffer, Note, Serious and Habitual Juvenile Offender Statutes: Reconciling Punishment and Rehabilitation Within the Juvenile System, 48 Vand. L. Rev. 479, 483-84 (1995). See also Stephan E. Oestreicher, Jr., Toward Fundamental Fairness in the Kangaroo Courtroom: The Due Process Case Against Statutes Presumptively Closing Juvenile Proceedings, 54 Vand. L. Rev. 1751, 1758 (2001) ("While the adult criminal justice system has largely abandoned the goal of rehabilitation, the youth justice system continues to identify it as a main objective.").

78. See SNYder \& Sickmund, supra note 49 , at 87.

79. Id. (reporting that as recently as 1997 , over thirty states continued to "emphasize ... prevention and treatment goals" in their juvenile code purpose clauses).

80. Id.

81. United States v. Jones, 332 F.3d 688, 690 (3d Cir. 2003), cert. denied, 124 S. Ct. 1145 (2004).

82. 42 Pa. Cons. Stat. § 6301(b)(2) (2000) (emphasis added). 
Mission Statement." 83 Pursuant to this focus on "youth redemption," the Benchbook instructs state juvenile judges to operate on the assumption that "juvenile offenders have strengths, are capable of change, can earn redemption, and can become responsible and productive members of their communities." ${ }^{\prime 4}$ Accordingly, the manual provides that the state juvenile justice system shall work to provide individualized and therapeutic methods of intervention in an effort to rehabilitate young offenders and release them back into society. ${ }^{85}$

Moreover, the fact that young offenders deemed either incapable or undeserving of complete rehabilitation are regularly transferred out of the juvenile system and into the nation's adult criminal courts provides additional evidence that the American juvenile system continues to value the "rehabilitative ideal." " The United States Supreme Court itself recognized a continued focus on rehabilitation in this context in Kent $v$. United States, ${ }^{87}$ when it held that, under certain circumstances, a juvenile court may effectively waive its exclusive jurisdiction over a minor defendant and transfer the youth to the adult criminal justice system for prosecution and punishment. ${ }^{88}$ In Kent, the Court expressly maintained that the juvenile court system is "theoretically engaged in determining the needs of the child and of society rather than adjudicating criminal conduct. The objectives are to provide measures of guidance and rehabilitation for the child and protection for society, not to fix criminal responsibility, guilt, and punishment." ${ }^{89}$ Hence, the Court's decision in Kent helped reinforce the idea that transfer policies act as a sort of "safety valve for the juvenile courts, a way to provide for punitive treatment of adolescents but still preserve the programs and policies of the juvenile court intact. ${ }^{, 90}$ In this sense, in the aftermath of Kent, juvenile courts routinely rely on waiver provisions to help handle two particularly problematic classes of young offenders:

83. Pennsylvania Juvenile Court Judges' Commission, Pennsylvania Juvenile DeLINQUENCY BeNCHBOOK 12 (2003), available at $\mathrm{http} / / / \mathrm{www} . j \mathrm{jc}$.state.pa.us/jcjc/lib/jcjc/benchbook.pdf (last visited Mar. 4, 2005).

84. Id. at 15 .

85. Id.

86. See generally Paul R. Kfoury, Children Before the Court: Reflections on Legal Issues AfFeCting Minors 75 (2d ed. 1991) (discussing the waiver of juvenile court jurisdiction).

87. Kent v. United States, 383 U.S. 541 (1966).

88. See KFoury, supra note 86 , at 75 ; see also Kent, 383 U.S. at 552-54.

89. Kent, 383 U.S. at 554.

90. Jeffrey Fagan \& Franklin E. Zimring, Editor's Introduction, in The Changing Borders of Juvenile Justice: Transfer of Adolescents to the Criminal Court 1, 2 (Jeffrey Fagan \& Franklin E. Zimring eds., 2000) [hereinafter The Changing Borders of Juvenile Justice]. 
In the case of seriously violent offenders, the public demands heavy penalties that have been well beyond the capacity of the juvenile justice system to provide. Whether these offenders might respond to juvenile justice intervention is irrelevant: the community simply will not tolerate mild responses to heinous crimes. The other class historically targeted for removal consists of chronic offenders who have been afforded all appropriate interventions at the juvenile court's disposal and who have not responded to those efforts. In such cases, the court reasonably concludes that they are not amenable to treatment. As a last resort, they are transferred to the criminal courts, which are better equipped to incapacitate those who present a continuing threat to the public welfare. ${ }^{91}$

In more recent years, an overwhelming majority of state legislatures have increasingly acknowledged the "rehabilitative ideal's" limited capacity to handle these serious and repeat offenders, and nearly every American jurisdiction is currently experiencing a trend toward standards that encourage waiver by the juvenile courts. ${ }^{92}$ For example, between the years of 1992 and 1995, forty-one states enacted laws making it easier to transfer juveniles into the adult criminal courts:

Again in 1996 and 1997, 25 states changed their statutes regarding jurisdiction of the juvenile courts - and again, virtually all of the new laws aimed to increase the number of youth transferred to criminal court. By the end of the 1997 legislative session, all except six states had enacted or expanded their juvenile transfer laws, and virtually every state allowed offenders as young as 14 to stand trial as adults in at least some circumstances. ${ }^{93}$

Pennsylvania is among those jurisdictions recognizing that the modern juvenile system's rehabilitative aims are not suited for all young offenders, and it has made clear that state juvenile judges currently have the broad discretion to transfer a juvenile to the state adult criminal courts should he or she conclude that the youth is not "amenable to treatment, supervision, or rehabilitation as a juvenile." 94 This statutory language, like that of other similar state waiver laws, effectively reaffirms the idea that the "dominant

91. Donna Bishop \& Charles Frazier, Consequences of Transfer, in The Changing Borders of JuVENILE Justice, supra note 90, at 227.

92. Id.

93. Richard A. Mendel,Less Hype, More Help: Reducing Juvenile Crime, What Works-And What Doesn't, American Youth Policy Forum 38 (2000), available at http://www.aypf.org/mendel/ MendelRep.pdf(last visited Mar. 4, 2005). See also Fagan \& Zimring, supra note 90, at 2 ("Between 1990 and 1996, no fewer than forty of the fifty states passed legislation creating new standards for transfer decisions. Without exception, these new laws were designed to expand the number and kind of cases where transfer occurs, but this expansive objective was pursued using a wide variety of tactics.") (citation omitted).

94. 42 Pa. Cons. Stat. § 6355(a)(4)(iii)(G) (2000). 
theory" of the modern juvenile court, the "need for treatment as the defining feature of the court's caseload, implied the basic rationale for waiving juveniles: a finding that the youth in question would likely not respond to treatment." 995

Finally, in the decades following its decision in Kent, the U.S. Supreme Court has also continued to endorse the "rehabilitative ideal" as a worthwhile aim of the juvenile justice system. ${ }^{96}$ These Court decisions have stressed the idea that young offenders often need protection from themselves because they lack proper judgment and frequently make poor decisions. ${ }^{97}$ In fact, as recently as 1984, in its Schall v. Martin opinion, the Supreme Court maintained that " $[\mathrm{t}] \mathrm{he}$ State has 'a parens patriae interest in preserving and promoting the welfare of the child, which makes a juvenile proceeding fundamentally different from an adult criminal trial." $" 98$ Moreover, the Schall Court also expressly provided that when arriving at juvenile detention sentences, judges must "specifically . . . consider the needs and best interest of the juvenile as well as the need for the protection of the community." this sense, through the language of these decisions, the Court has left absolutely no doubt that rehabilitation remains a primary goal of the juvenile system in the modern era.

2. The Current Juvenile Justice System Does Not Provide Young Offenders With the Same Constitutional Procedural Safeguards Afforded to Adult Criminal Defendants

In the Supreme Court's opinion in Gault, Justice Abe Fortas accurately noted that "from the inception of the juvenile court system, wide differences have been tolerated - indeed insisted upon - between the procedural rights accorded to adults and those of juveniles." ${ }^{100}$ Although the Supreme Court has embarked on a sort of "due process revolution" of the juvenile system in the

95. Fagan \& Zimring, supra note 90 , at 5.

96. See, e.g., Schall v. Martin, 467 U.S. 253, 266 (1984) (holding that society "has a legitimate interest in protecting a juvenile from the consequences of his [own] criminal activity"); Smith v. Daily Mail Publ'g Co., 443 U.S. 97, 107-08 (1979) (Rehnquist, J., concurring) (maintaining that rehabilitation increases a juvenile's "prospects for adjustment in society and acceptance by the public").

97. See Bellotti v. Baird, 443 U.S. 622, 635 (1979) (ruling that "during the formative years of childhood adolescence, minors often lack the experience, perspective, and judgment to recognize and avoid choices that could be detrimental to them").

98. Schall, 467 U.S. at 263 (quoting Santosky v. Kramer, 455 U.S. 745, 766 (1982)).

99. Id. at 264 .

100. In re Gault, 387 U.S. 1, 14 (1967). 
years following that decision, the overall reluctance to abandon the rehabilitative ideal has ensured that significant differences persist between the constitutional procedural protections involved in juvenile adjudications and adult criminal proceedings. ${ }^{101}$ Moreover, in the words of Barry C. Feld, arguably the most preeminent legal scholar in the field of juvenile justice, ${ }^{102}$ many young offenders in today's juvenile system "do not receive even the limited procedural justice that Gault envisioned. . . . [M]ost states do not provide youths with either procedural safeguards equivalent to those of adult criminal defendants, or with special procedures that more adequately protect them from their own immaturity." "103

Recent empirical and evaluative studies, as well as survey research, have confirmed Feld's observation, suggesting that the modern juvenile system has largely failed to deliver the enhanced procedural justice envisioned by the Gault Court. ${ }^{104}$ For example, a 1994 survey found that juvenile court workers, including almost half of the juvenile court judges surveyed, witnessed judicial behavior which they felt significantly compromised many young offenders' ability to get a fair trial:

This conduct included forcing unprepared parties to proceed with trial or a guilty plea, interrupting the lawyers' witness examinations with their own questions, and cutting off the lawyers' questioning. Two-thirds of the surveyed court workers noted that juvenile court judges often had knowledge before trial of the accused juvenile's prior criminal record and of the recommended disposition from the probation officer, and a majority of the respondents thought that this knowledge created a bias in the judge against the juvenile. ${ }^{105}$

Similarly, over a third of the study's participants reported that they felt juvenile judges admitted evidence that should have been excluded under the

101. See Chamberlin, supra note 45, at 397 ("Unfortunately, loose procedures ... all too often, have resulted in depriving some juveniles of fundamental rights that have resulted in a denial of due process.") (quoting Gault, 387 U.S. at 19).

102. See Janet E. Ainsworth, The Court's Effectiveness in Protecting the Rights of Juveniles in Delinquency Cases, 6 The Future of Children: The Juv. CT. 64 \& n.9 (1996), available at http:// www.futureofchildren.org/usr_doc/vol6no3ART5.pdf(last visited Mar. 4, 2005) (regarding Barry C. Feld as "without a doubt the most prolific scholar of the juvenile justice system").

103. Barry C. Feld, Violent Youth and Public Policy: A Case Study of Juvenile Justice Law Reform, 79 Minn. L. Rev. 965, 1099 (1995). See also Ainsworth, supra note 102, at 65-66 (noting that "it is not clear the degree to which this due process revolution has changed the actual day-to-day practices of the parties participating in juvenile court adjudication, many of whom have been overly hostile to the imposition of formal procedural due process requirements").

104. Ainsworth, supra note 102, at 66.

105. $I d$. 
jurisdiction's rules of evidence. ${ }^{106}$ Moreover, many of the respondents expressed their beliefs that juvenile proceedings were conducted too quickly and that the atmosphere in the juvenile courtroom was neither serious nor formal enough to provide youth offenders with an adequate means of justice. ${ }^{107}$ As a result, the study affirmatively concluded that "the procedural deficiencies of the juvenile court system were worse than those of the adult system." 108

Perhaps the most striking procedural difference between the current adult and juvenile justice systems is the fact that an overwhelming number of jurisdictions, including Pennsylvania, do not afford juveniles the right to a trial by jury. ${ }^{109}$ In McKeiver v. Pennsylvania, the U.S. Supreme Court expressly declined to extend the right to a jury trial to young offenders, reasoning that "the juvenile court proceeding has not yet been held to be a 'criminal prosecution,' within the meaning and reach of the Sixth Amendment, and also has not yet been regarded as devoid of criminal aspects merely because it usually has been given the civil label."110 The McKeiver Court added that by affording all young offenders a trial by jury, juvenile adjudications would be transformed into a completely adversarial process that would defeat the "idealistic prospect" of the intimate and informal protective proceeding traditionally associated with the juvenile courts. ${ }^{111}$ As a result, the Court concluded that the main procedural safeguard necessary to provide "fundamental fairness" to young offenders is "accurate fact finding," a requirement the Court felt could easily be satisfied by a judge sitting in place of a jury. ${ }^{112}$

The Court's ruling in McKeiver directly conflicts with its earlier holding in Duncan v. Louisiana, ${ }^{113}$ which provided that states must afford criminal defendants the constitutional right to a jury trial. ${ }^{114}$ In Duncan, the Supreme Court expressly mandated that the notion of fundamental fairness in adult

106. $I d$.

107. $I d$.

108. Id. at 66 .

109. Id. at $67 \&$ n.24 (reporting that the only states granting juveniles the right to a jury trial are Alaska, Colorado, Kansas, Michigan, Minnesota, Montana, New Mexico, Oklahoma, Tennessee, Texas, West Virginia, Wisconsin, and Wyoming).

110. McKeiver v. Pennsylvania, 403 U.S. 528, 541 (1971).

111. Id. at 545 .

112. Id. at 547 .

113. Duncan v. Louisiana, 391 U.S. 145 (1968).

114. Feld, Justice For Children, supra note 54, at 272. 


\section{criminal proceedings requires the presence of a jury to ensure both factual accuracy and protection from government oppression:}

A right to a jury trial is granted to criminal defendants in order to prevent oppression by the Government. Those who wrote our constitutions knew from history and experience that it was necessary to protect against unfounded criminal charges brought to eliminate enemies and against judges too responsive to the voice of higher authority.... Providing an accused with the right to be tried by a jury of his peers gave him an inestimable safeguard against the corrupt or overzealous prosecutor and against the compliant, biased, or eccentric judge. If the defendant preferred the common-sense judgment of a jury to the more tutored but perhaps less sympathetic reaction of the single judge, he was to have it. Beyond this, the jury trials provisions ... reflect a fundamental decision about the exercise of official power - a reluctance to entrust plenary powers over the life and liberty of the citizen to one judge or to a group of judges. Fear of unchecked power ... found expression in the criminal law in this insistence upon community participation in the determination of guilt or innocence. ${ }^{115}$

In this sense, the Duncan Court recognized that juries serve important functions that exceed the limited "fact-finding" role assigned to them in McKeiver and remain an integral constitutional procedural safeguard from government abuse and unchecked discretion. ${ }^{116}$

In light of the Court's observations in Duncan, it should be no surprise that studies have shown that denial of the right to a jury trial has harmed

115. Duncan, 391 U.S. at 155-56.

116. Id. In a recent law review article, Professor Barry Feld discussed the gap between the Court's reasoning in Apprendi and McKeiver and suggested that the two decisions could only be reconciled by a complete overruling of McKeiver. See Barry C. Feld, The Constitutional Tension Between Apprendi and McKeiver: Sentence Enhancements Based on Delinquency Convictions and the Quality of Justice in Juvenile Courts, 38 WAKe Forest L. REv. 1111, 1224 (2003). To support this conclusion, Feld proffered: McKeiver's uncritical and out-dated plurality decision is ripe for overruling. Judicial, legislative, and administrative changes have transformed the juvenile court into a very different institution than the one that McKeiver considered more than three decades ago. At best, the contemporary juvenile court functions as little more than a scaled-down, second-class criminal justice system for youths that provides neither therapy nor justice. Notwithstanding McKeiver's fond hopes, juvenile courts' adjudicative functions simply replicate those of criminal courts, albeit with fewer, less adequate procedural protections. Providing delinquents with a constitutional or statutory right to a jury trial would mitigate the unfairness of using procedurally deficient, factually unreliable convictions to enhance subsequent sentences. States which deny delinquents jury trials in the contemporary punitive juvenile justice system compound that inequity when they use those nominally rehabilitative sentences to extend terms of adult imprisonment.

Id. (citations omitted). Because, as stated above, this Note rejects the idea that the modern juvenile system is inherently punitive and only nominally rehabilitative, it does not assume Professor Feld's extreme position that the Supreme Court must overrule McKeiver. Instead, it merely asserts that the Supreme Court's reluctance to extend the right to a jury trial to young offenders is more evidence that procedural due process should bar judges from using nonjury juvenile adjudications interchangeably with past adult criminal convictions for purposes of ACCA sentence enhancement. 
juvenile offenders in many ways. ${ }^{117}$ First, and most importantly, a youth tried in juvenile court is more likely to be found delinquent by a judge than if tried by a detached jury, as in an adult criminal proceeding, based on the same evidence. ${ }^{118}$ Juries are less likely than judges to convict for several reasons, most notably because in today's crowded courts judges hear hundreds of cases a year while most jurors only take part in one or two over the course of their lifetimes:

Having to sit on so many cases, judges may become less careful in weighing the evidence and more cynical in evaluating the credibility of the juveniles who appear before them. This is all the more likely when they know before trial of the juvenile's prior record, have heard the motion to suppress a confession, or have read the probation officer's report on the juvenile's social background. ${ }^{119}$

Additionally, jury trials provide the parties with an opportunity to examine potential jurors in voir dire proceedings and exclude individuals whose personal biases may prevent them from fairly trying a particular case, while no comparable opportunity to explore such prejudices exists in juvenile adjudications. ${ }^{120}$ Moreover, in a trial by jury, jurors must be carefully instructed in how to apply the law to a particular set of facts through written jury instructions, and any error of law can later be reviewed by an appellate court. ${ }^{121}$ However, when a judge tries a case alone, he or she need not always expressly record his or her understanding of the law, making it difficult for reviewing courts to ascertain whether the judge may have applied the law in a way that was detrimental to an individual young offender. ${ }^{122}$ Thus, depriving juveniles of the right to a jury trial leaves them at a "double disadvantage" when compared with adult criminal defendants because they are both more likely to be found "delinquent" at trial and less likely to be able to show reversible error on appeal. ${ }^{123}$ Finally, since many defendants, both juvenile and adult alike, plead guilty instead of proceeding to trial, "[i]n the course of a plea bargaining, the possibility that a defendant will elect to

117. See Ainsworth, supra note 102, at 67-68; see also FeLd, JustiCe For Children, supra note 54, at 271 .

118. Feld, Justice For Children, supra note 54, at 271.

119. Ainsworth, supra note 102, at 68.

120. Id. See also Feld, Justice For Children, supra note 54, at 271 ("While litigants may examine jurors about their attitudes, beliefs, and experiences that may bear upon the way they will decide the case, there is no comparable opportunity to explore a judge's background to determine the presence of judicial biases.").

121. Ainsworth, supra note 102 , at 68 .

122. Id.

123. Id. 
exercise the constitutional right to a jury trial is a potent bargaining chip" unavailable in juvenile proceedings. ${ }^{124}$

\section{Final Analysis}

The juvenile and adult criminal justice systems vary in both purpose and procedure, which makes it unconstitutional for courts to use prior nonjury juvenile adjudications interchangeably with past adult criminal convictions when determining whether to extend or enhance the later sentence of an adult repeat offender like Lester Jones. Since the juvenile system of justice was founded on the principle of rehabilitation, and continues to embrace the "rehabilitative ideal" in modern times, there are significant constitutional differences in the degree of procedural due process and fundamental fairness involved in adult convictions and juvenile adjudications. As a result of this gross disparity, the Third Circuit erred in holding that juvenile adjudications subject to less stringent procedural standards than adult criminal proceedings may properly be characterized as "prior convictions" for purposes of the Supreme Court's Apprendi decision. Consequently, the Jones court should have instead recognized that the Fifth Amendment dictates that Apprendi's general rule must be limited to prior convictions that were themselves obtained through proceedings affording individual defendants the same procedural safeguards they would be entitled to in the adult criminal justice system.

\section{CONCLUSION}

In sum, although Lester Jones and other fellow habitual criminal offenders are by no means model citizens, they are certainly entitled to at least the enumerated procedural safeguards that our Constitution affords to all criminal defendants. While it is sometimes tempting for judges and other members of our society to look past these guarantees in cases involving repeat offenders, courts must remember that the Bill of Rights, and particularly the Fifth Amendment, works to protect individuals from oppressive government conduct and not merely to provide criminals with procedural loopholes to help them avoid convictions or, in this case, enhanced sentences. By refusing to acknowledge this fundamental principle, the Jones court tainted the integrity of the present-day criminal justice system by unabashedly trampling on 
traditionally protected due process rights and creating a dangerous precedent that will require sentencing judges throughout the Third Circuit to follow in its unconstitutional footsteps.

On January 20, 2004, the United States Supreme Court denied a petition for certiorari filed by Lester Jones and his attorneys. ${ }^{125}$ Further, in its recent consolidated review of two lower federal court decisions, United States $v$. Booker ${ }^{126}$ and United States v. Fanfan, ${ }^{127}$ which dramatically overhauled federal sentencing practices by reaffirming Apprendi's original mandate that "[a]ny fact (other than a prior conviction) which is necessary to support a sentence exceeding the maximum authorized . . . must be admitted by the defendant or proved to a jury beyond a reasonable doubt," the Court once again missed a significant opportunity to expressly resolve whether a prior non-juvenile adjudication constitutes a "prior conviction" for purposes of the Apprendi exemption. ${ }^{128}$ In order to prevent the sort of injustice promulgated by the Third Circuit in Jones, as well as to eliminate further confusion and conflicting results among the rest of the federal appellate courts, the Court should have used Booker and Fanfan, and their widespread implications on federal sentencing procedures, to settle this important issue once and for all. However, because the Court inexplicably failed to do so, it must now work to clarify the current federal sentencing scheme in a way that will help reverse the wrongs of the Jones court and interpret the Constitution's due process guarantees to protect convicted adult criminal defendants from having their sentences enhanced by prior juvenile adjudications in which they were not afforded the basic procedural safeguards inherent to adult criminal proceedings. In this sense, the Court must pay heed to the words of former Supreme Court Justice William Day and reinforce the idea that " $[\mathrm{t}]$ he efforts of the courts and their officials to bring the guilty to punishment, praiseworthy as they are, are not to be aided by the sacrifice of those great principles established by years of endeavor and suffering which have resulted in their embodiment in the fundamental law of the land." ${ }^{29}$ To hold otherwise, the Court would only widen the disparity between individual criminal defendants and modern government that the Fifth Amendment's due process guarantee was specifically designed to remedy.

125. United States v. Jones, 332 F.3d 688 (3d Cir. 2003), cert. denied, 124 S. Ct. 1145 (2004).

126. United States v. Booker, 125 S. Ct. 738 (2005).

127. United States v. Fanfan, 125 S. Ct. 738 (2005).

128. $I d$. at 756 (emphasis added).

129. Weeks v. United States, 232 U.S. 383, 393 (1914). 